\title{
RESPONSE OF POTATO YIELD AND QUALITY TO BIO-ORGANIC MANURES AS AN ALTERNATIVE STRATEGY TO AVOID THE POSSIBLE CHEMICAL POLLUTION OF MINERAL FERTILIZERS
}

\author{
Samira E. Mahrous
}

Soils, Water and Environ. Res. Inst., Agric. Res. Center, Giza, Egypt

ABSTRACT:

A field experiment was conducted on a newly reclaimed sandy soil at ElShark Farm, El-Nubaria area, El-Beheira Governorate, Egypt during two successive seasons of 2007-2008 and 2008-2009. This study aimed at evaluating the effect of completely or partial substitution of the recommended N-mineral dose by $\mathrm{N}$ derived from bio-organic sources, i.e., organic compost, bioinoculation with $\mathrm{N}_{2}$-fixer bacteria of Cyanobacteria and P-dissolving bacteria of Bacillus megatherium var. phosphaticum + rock phosphate and K-sulphate as well as amino acids as foliar spray on potato tuber yield and quality. The expected amelioration of soil nutrients status was also taken into consideration. This scientific aspect represents a new strategy technique for understanding the best usage of local natural organic manure and active bacterial strains for $\mathrm{N}$ or $\mathrm{P}$ bio-inoculation, whether be under demand for agricultural utilization projects in the newly reclaimed areas. It is considered a huge challenge and technical solution for alleviating the possible adverse fears of environmental chemical pollution risks as a result of excessive use of the nitrogenous fertilizers as well as to support the newly approach of "bio-organic agriculture".

To achieve this target, bio-inoculated potato tubers (Solanum tuberosum, L., Lady balfour cv.) were sown under the aforementioned conditions of the experimental soil and applied treatments as solely or combined with amino acids added as foliar spray at the rate of $150 \mathrm{~g} / 100 \mathrm{~L} / \mathrm{fed}$. The obtained results indicated that the experimental soil could be classified as "Typic Torripsamments, siliceous, thermic". In addition, the suitability class for irrigated agriculture land could be belong a marginally one $\left(\mathrm{S}_{3} \mathrm{~s}_{1} \mathrm{~s}_{4}\right)$. Also, the resultant adaptations of soil suitability class for cultivating potato plants could be considered as a marginally suitable adaptation $\left(\mathrm{S} 3 \mathrm{~s}_{1} \mathrm{n}\right.$ for the current and $\mathrm{S} 3 \mathrm{~s}_{1}$ for the potential conditions), with soil texture $\left(\mathrm{s}_{1}\right)$ as a limiting factor.

Results indicated that the addition of organic compost into the soil significantly increased the available macro and micronutrient contents. This is more attributed to it represents as a strategic storehouse for essential plant nutrients, which are slow release during their mineralization processes, minimizing their possible lose by leaching process and increasing soil potential of retained nutrients-moisture for grown plants or organisms. Also, application of biofertilizer as inoculated tuber pieces and amino acids as foliar spray significantly increased the availability and mobility of nutrients in the soil as well as their uptake by plant roots and accumulation in potato shoots and tuber tissues. These favourable conditions were positively reflected on vegetative growth parameters, i.e., plant height, Nos. of leaves and branches plant ${ }^{-1}$ and shoots dry matter plant ${ }^{-1}$ as well as potato yield and tuber quality throughout ameliorating the values of dry matter \%, total carbohydrates $\%$, crude protein \% and tuber contents of $\mathrm{N}, \mathrm{P}, \mathrm{K}, \mathrm{Fe}, \mathrm{Mn}, \mathrm{Zn}, \mathrm{Cu}$ and $\mathrm{B}$. That was true, since the

Fayoum J. Agric. Res. \& Dev., Vol.25, No.1, January, 2011 
combined treatment of organic compost, biofertilizer and sprayed with amino acid resulted in a best tuber yield with high quality.

So that, it could be recommended that organic manure, P-dissolving bacteria and $\mathrm{N}_{2}$-fixer bacteria strains should be used to face a great problem of chemical pollution of the exportable potato tuber yield due to the excessive mineral fertilizer uses. Hence, such favourable conditions should be enhance continuous agricultural bio-organic system as a slow release nutrients along the growth stages of potato plants, and in turn to minimize its possible nutrients losses, which represent surplus point for sustainable agriculture system.

Key words: Potato, organic compost, bio-fertilizer, tuber yield and quality.

\section{INTRODUCTION:}

Potato (Solanum tuberosum L.) is the fourth most important crops, after rice, wheat, and maize (Spooner and Bamberg, 1994). Also, it is one of the most important vegetable crops cultivated in Egypt for local consumption and exportation due to a major source of inexpensive energy. However, it contains high levels of carbohydrates and significant amount of vitamins $\mathrm{B}$ and $\mathrm{C}$ and minerals. Hence, more attention was given to increase the quality of potato for exportation by using other new technologies of combating chemical pollution, however, application of mineral nitrogen and phosphatic fertilizers are commonly caused such problem. Moreover, taking the economical point into account, the high prices of such mineral fertilizers can be increased the production costs of potato producers. Therefore, the use of bio-organic manures is a particular interest to avoid the previously mentioned problem.

At the same times, the low soil fertility, which represents a major problem that has been facing by all farmers, is caused by continuous cropping and heavy application of inorganic fertilizer or chemical fertilizer. Further, the biofertilizer was introduced to decrease chemical fertilizer application and increase the crop production. To achieve high production value targets, preservation of sustainable agriculture resources needs effort and appropriate strategies including the utilization of biofertilizers and organic manures. Lately, farmers have started to give greater attention to the application of biofertilizer. Dilfuza (2007) reported that microorganisms are important in agriculture in order to promote the circulation of plant nutrients and reduce the need for mineral fertilizers as much as possible. Bacteria inoculants are able to speed up seed germination, improve seedlings emergence and then increase plant growth as well as response to external stress factors and protect plant against diseases (Lugtenberg et al, 2002). Plant growth promoting bacteria plays an important role for plant nutritional status by increasing $\mathrm{N}$ and $\mathrm{P}$ uptake (Cakmakci et al., 2005).

One of these driving forces is the farmer awareness of the potential environmental pollution through the use of excessive chemical fertilizers (Simanungkalit, 2001). According to Havlin et al. (2005), the use of inorganic fertilizer continuously will cause damage on physical, chemical and biological properties of soil, so that the soil fertility will be more decreased. Renewed interest in organic farming has resulted in a need for research in sustainable farming practices (Bull, 2006; Dimitri and Oberholtzer, 2006). Demand for organic produce is expected to increase as people in an increasingly urban society become concerned about food quality. In organic agriculture, nitrogen management is accomplished by applying organic materials such as compost. Organic nitrogen is locked up in organic molecules and cannot be utilized by plants until it is converted

Fayoum J. Agric. Res. \& Dev., Vol.25, No.1, January, 2011 
to inorganic nitrogen through a complex series of biochemical reactions known as mineralization. On the positive side, organic sources provide a reservoir of nitrogen that is released slowly by the organisms of the soil food web. However, nitrogen management is more complicated because nitrogen cannot be readily applied throughout the season. Demand for organic produce is expected to increase as people in an increasingly urban society become concerned about food quality. Organic fertilizer is a substance that is important in improving the biological properties of the soil so as to create a better environment for plant roots. Utilization of organic materials and micro-organisms is useful to develop sustainable agriculture and to minimize the use of inorganic chemicals (Ghorbani et al., 2008). Therefore, the biofertilizers were introduced as alternative fertilizers for reducing application of the chemical fertilizers and preserving the environment in the long run (Mezuan et al., 2004). Using organic fertilizer in potato production is growing at Egypt now to take place in European market and to have the consumer who is willing to pay high price for a healthy safe product. Potato requires high amounts of K-fertilizer for optimum growth, production and tuber quality. The main source of $\mathrm{K}$ for plants comes from $\mathrm{K}$-minerals and organic $\mathrm{K}$-source, $\mathrm{K}$ feldspar is one of the most important K-minerals (Straaten, 2002).

Makaraviciute (2003) found that organic manure application slightly increased the tuber contents of dry matter, starch and total carbohydrates, while mineral fertilization gave the highest tuber yield. Also, farmyard manure application increased dry matter and starch by $20 \%$. Abou-Hussein et al. (2002) reported that applying compost with chicken manure and biofertilizer increased the percentage of nutrients in potato leaves, dry matter content, total carbohydrates and total yield per plant. Sarhan et al. (2004) pointed out organic manure was a saviour fertilizer as compared to the mineral ones. Thus, the proper fertilization can prevent or greatly reduce the potential contamination from heavy metals of plants and soil. Bakry et al. (2009) reported that addition of organic manure to the soil encourage proliferation of soil microorganisms, increased microbial populations and activity of microbial enzymes, i.e., dehydrogenase urease and nitrogenase. These results are emphasized by El-Mancy et al. (2008) who found that application or organic manure was more effective for increasing potato yield grown under a relatively coarse-textured soil.

The current work was aimed at identifying the integrated effect of applied organic compost in combination with effective microorganisms of bacteria strains and amino acids on potato tuber yield and quality grown on a newly reclaimed sandy soil. Also, the effective roles of the applied treatments on available nutrient contents in the soil would be a matter of concern in this study.

\section{MATERIALS AND METHODS:}

To achieve the aforementioned objectives, a field experiment was executed on a newly reclaimed sandy soil at El-Shark Farm, El-Nubaria area, El-Beheira Governorate, Egypt during two successive seasons of 2007-2008/2008-2009. Some physical and chemical properties as well as some nutrients status of the studied soil in which the experiment was carried out were determined according to the standard methods outlined by Black et al. (1965), Chapman and Pratt (1961) and Jackson (1973), and the obtained results are presented in Table (1).

The used organic compost as well as supplementary with a partial (bio- $\mathrm{N}_{2}$ fixer) or (bio-P-dissolving bacteria + rock phosphate) and K-sulphate treatments were applied to overcome the recommended doses of $\mathrm{N}, \mathrm{P}$ and $\mathrm{K}$-mineral, i.e., 120$150 \mathrm{~N} \%$, 30-45 $\mathrm{P}_{2} \mathrm{O}_{5} \%$ and $96 \mathrm{~K}_{2} \mathrm{O} \%$, respectively, according to Horticulture

Fayoum J. Agric. Res. \& Dev., Vol.25, No.1, January, 2011 
Dept., Ministry of Agriculture, Egypt. The experimental design was a split plot with three replicates, however, the previous treatments were occupied the main plots. Meanwhile the applied amino acids as foliar spray were arranged into the sub-plots. Some chemical characters of used organic compost and rock phosphate are presented in Table (2)

Table (1): Some physical, chemical and fertility characteristics of the studied soil.

\begin{tabular}{|c|c|c|c|c|c|c|c|c|}
\hline \multicolumn{3}{|c|}{\begin{tabular}{|l|l} 
Soil characteristics & \\
\end{tabular}} & Value & \multicolumn{4}{|c|}{ Soil characteristics. } & Value \\
\hline \multicolumn{4}{|c|}{ Particle size distribution \%: } & \multicolumn{5}{|c|}{ Analysis of soil paste extract: } \\
\hline \multicolumn{2}{|c|}{ Sand } & \multicolumn{2}{|c|}{92.82} & \multirow{2}{*}{\multicolumn{4}{|c|}{$\begin{array}{l}\mathrm{EC}(\mathrm{dS} / \mathrm{m}) \\
\text { Soluble cations }\left(m \text { molc } L^{-1}\right):\end{array}$}} & 2.40 \\
\hline \multicolumn{2}{|l|}{ Silt } & \multicolumn{2}{|c|}{2.43} & & & & Soluble cations $\left(\mathrm{m}\right.$ molc $\left.L^{-1}\right)$ : & \\
\hline \multicolumn{2}{|l|}{ Clay } & \multicolumn{2}{|c|}{4.75} & \multicolumn{4}{|c|}{$\overline{\mathrm{Ca}^{++}}$} & 9.32 \\
\hline \multicolumn{2}{|c|}{ Textural class } & \multicolumn{2}{|c|}{ Sandy } & \multicolumn{4}{|c|}{$\mathrm{Mg}^{++}$} & 3.68 \\
\hline \multicolumn{2}{|c|}{$\mathrm{CaCO}_{3} \%$} & \multicolumn{2}{|c|}{4.93} & \multicolumn{4}{|c|}{$\begin{array}{l}\mathrm{Na}^{+} \\
\mathrm{K}^{+}\end{array}$} & 11.20 \\
\hline \multicolumn{4}{|c|}{ Soil available nutrients $\left(\mathrm{mg} \mathrm{kg}^{-1}\right)$ : } & \multicolumn{5}{|c|}{ Soluble anions $\left(m\right.$ molc $\left.L^{-1}\right)$ : } \\
\hline \multicolumn{2}{|c|}{$\mathrm{N}$} & \multicolumn{2}{|c|}{21.34} & \multicolumn{4}{|c|}{$\mathrm{CO}_{3}^{--}$} & 0.00 \\
\hline \multicolumn{2}{|l|}{$\mathrm{P}$} & \multicolumn{2}{|c|}{3.65} & \multicolumn{4}{|c|}{$\mathrm{HCO}_{3}^{-}$} & 1.75 \\
\hline \multicolumn{2}{|l|}{ K } & \multicolumn{2}{|c|}{54.70} & \multicolumn{4}{|c|}{$\mathrm{Cl}^{-}$} & 13.00 \\
\hline \multicolumn{2}{|l|}{$\mathrm{Fe}$} & \multicolumn{2}{|c|}{4.30} & \multicolumn{4}{|c|}{$\mathrm{SO}_{4}^{--}$} & 9.80 \\
\hline $\mathrm{Mn}$ & & 0.8 & & Orga & ic matter & & & 0.15 \\
\hline $\mathrm{Zn}$ & & 0.6 & & $\mathrm{pH}($ & 2.5 soil w & r suspens & & 8.15 \\
\hline $\mathrm{Cu}$ & & 0.4 & & Gyps & $\mathrm{m} \%$ & & & 0.87 \\
\hline $\mathrm{B}$ & & $\mid 0.3$ & & ESP & & & & 4.35 \\
\hline Criti & al levels of & utrients $a$ & ter 1 & ndsay & id Norvel & 1978) and & age et al & 982) \\
\hline Limits & $\mathrm{N}$ & $\mathrm{P}$ & & $\mathrm{K}$ & $\mathrm{Fe}$ & $\mathrm{Mn}$ & $\mathrm{Zn}$ & $\mathrm{Cu}$ \\
\hline Low & $<40.0$ & $<5.0$ & & 85.0 & $<4.0$ & $<2.0$ & $<1.0$ & $<0.5$ \\
\hline Medium & $40.0-80.0$ & $5.0-10.0$ & & 170.0 & $4.0-6.0$ & $2.0-5.0$ & $1.0-2.0$ & $0.5-1.0$ \\
\hline High & $>80.0$ & $>10.0$ & & 70.0 & $>6.0$ & $>5.0$ & $>2.0$ & $>1.0$ \\
\hline
\end{tabular}

Table (2): Some chemical characters of used compost and rock phosphate.

\begin{tabular}{|l|c|c|}
\hline \multicolumn{1}{|c|}{ Parameter } & Compost & Rock phosphate \\
\hline Weight of $1 \mathrm{~m}^{3}(\mathrm{~kg})$ & 600 & -- \\
\hline $\mathrm{EC}(\mathrm{dS} / \mathrm{m}, 1: 10$ water suspension $)$ & 4.78 & -- \\
\hline $\mathrm{pH}(1: 10$ water suspension) & 7.63 & -- \\
\hline Organic matter \% & 46.13 & -- \\
\hline Organic carbon \% & 26.82 & -- \\
\hline $\mathrm{C} / \mathrm{N}$ ratio & 19.87 & -- \\
\hline \multicolumn{2}{|c|}{ Total contents of some macronutrients $\%$} \\
\hline $\mathrm{N}$ & 1.35 & -- \\
\hline $\mathrm{P}$ & 0.47 & 0.48 \\
\hline $\mathrm{K}$ & 2.35 & 0.32 \\
\hline $\mathrm{Ca}$ & 3.87 & 1.82 \\
\hline $\mathrm{Mg}$ & 0.93 & 0.41 \\
\hline $\mathrm{Fe}$ & 0.053 & 28.55 \\
\hline \multicolumn{2}{|c|}{ Available contents of some micronutrients $\left(\mathrm{mg} \mathrm{kg}^{-1}\right)$} \\
\hline $\mathrm{Mn}$ & 248.55 & 19.55 \\
\hline $\mathrm{Zn}$ & 69.55 & 11.85 \\
\hline $\mathrm{Cu}$ & 32.05 & 5.8 \\
\hline $\mathrm{B}$ & 8.60 & \\
\hline
\end{tabular}

Fayoum J. Agric. Res. \& Dev., Vol.25, No.1, January, 2011 
Thus, the applied treatments were as follows:

a. Main plots (organic compost or a partial substitution by each of $\mathrm{N}_{2}$-fixer bacteria, P-dissolving bacteria, rock phosphate, K-sulphate treatments).

$\mathrm{C}_{1} \approx$ completely recommended $\mathrm{N}, \mathrm{P}$ and $\mathrm{K}$-mineral substitution doses by full dose of organic compost $\left(25 \mathrm{~m}^{3} / \mathrm{fed} \approx 15\right.$ ton/fed $)$.

$\mathrm{C}_{2} \approx 3 / 4$ of full dose of organic compos $\left(18.75 \mathrm{~m}^{3} / \mathrm{fed} \approx 11.25\right.$ ton/fed $)$, supplementary with a partial substitution by tuber bio-inoculation $\left(\mathrm{N}_{2}\right.$-fixer bacteria of Cyanobacteria, rock phosphate at a rate of $150 \mathrm{~kg} / \mathrm{fed}+\mathrm{P}-$ dissolving bacteria of Bacillus megatherium var. phosphaticum) and potassium sulphate of $\mathrm{K}_{2} \mathrm{O} 48 \%$ at a rate of $50 \mathrm{~kg} / \mathrm{fed}$.

$\mathrm{C}_{3} \approx 1 / 2$ of full dose of organic compos $\left(12.50 \mathrm{~m}^{3} / \mathrm{fed} \approx 7.50\right.$ ton/fed $)$, supplementary with a partial substitution by either tuber bio-inoculation $\left(\mathrm{N}_{2}\right.$-fixer bacteria of Cyanobacteria, rock phosphate at a rate of $250 \mathrm{~kg} / \mathrm{fed}$ + P-dissolving bacteria of Bacillus megatherium var. phosphaticum) and potassium sulphate of $\mathrm{K}_{2} \mathrm{O} 48 \%$ at a rate of $100 \mathrm{~kg} / \mathrm{fed}$.

$\mathrm{C}_{4} \approx 1 / 4$ of full dose of organic compos $\left(6.25 \mathrm{~m}^{3} / \mathrm{fed} \approx 3.75\right.$ ton/fed $)$, supplementary with a partial substitution by tuber bio-inoculation $\left(\mathrm{N}_{2}\right.$-fixer bacteria of Cyanobacteria, rock phosphate at a rate of $325 \mathrm{~kg} / \mathrm{fed}+\mathrm{P}-$ dissolving bacteria of Bacillus megatherium var. phosphaticum) and potassium sulphate of $\mathrm{K}_{2} \mathrm{O} 48 \%$ at a rate of $150 \mathrm{~kg} / \mathrm{fed}$.

b. Sub-plots (amino acids as foliar spray):

$\mathrm{A}_{0} \approx$ control treatment (untreated with amino acids).

$\mathrm{A}_{1} \approx$ treated with amino acids at a rate of $150 \mathrm{~g} / 100 \mathrm{~L}$ per fed, into two equal doses at flowering and two weeks before harvest stages.

The two kinds of bacteria strains used as bio-fertilizers and growth promoters in this experiment are kindly supplied with the Agric. Microbial Res. Dept., Soils, Water and Environ. Res. Inst., Agric. Res. Center, Giza, Egypt. The used organic compost at a rate of $25 \mathrm{~m}^{3} / \mathrm{fed} \approx$ full dose, rock phosphate at the rate of 150-325 $\mathrm{kg} / \mathrm{fed}$ and $\mathrm{K}$-sulphate of $48 \mathrm{~K}_{2} \mathrm{O} \%$ at the rate of $50-150 \mathrm{~kg} / \mathrm{fed}$ were added to the soil before planting, and thoroughly mixed with the $20 \mathrm{~cm}$ surface layer of the soil. Each experimental plot, with an area of $10.5 \mathrm{~m}^{2}(3.0 \times 3.5 \mathrm{~m})$, contained 4 rows $(3$ $\mathrm{m}$ length and $0.7 \mathrm{~m}$ width). Potato tuber pieces were successfully washed with water and air-dried, thereafter, the coated pieces with inoculums of a mixture from bacteria of Cyanobacteria and Bacillus megatherium var. phosphaticum $(1 \mathrm{~mL}$ contains $8 \times 10^{7}$ viable cell) for 30 minutes just before planting using a solution of $10 \%$ Arabic gum as adhesive agents. Bio-inoculated potato tuber pieces were sown on $10^{\text {th }}$ and $15^{\text {th }}$ of February in the first and second growing seasons of 2007-2008 and 2008-2009, respectively. All the experimental plots received the same amounts of irrigation water from planting till harvest through a sprinkler irrigation system.

At 70 days from planting, plant samples were collected from the two middle ridges in each plot to determine some vegetative growth parameters, i.e., plant height, Nos. of leaves and branches plant ${ }^{-1}$ and shoots dry matter plant ${ }^{-1}$. At the same times, soil samples were taken from the same sites to determine soil content of available nutrients as affected by the different applied treatments. Available nitrogen was extracted by $\mathrm{KCl}$ solution of $2 \mathrm{M}$ and determined by using Technician Auto Analyzer according to Markus et al. (1982), $\mathrm{P}$ and $\mathrm{K}$ were determined according to Jackson (1973). Available $\mathrm{Fe}, \mathrm{Mn}, \mathrm{Zn}, \mathrm{Cu}$ and $\mathrm{B}$ were determined according to Cottenie et al. (1982).

Also, at harvest stage, i.e., 120 days from planting, potato tubers were collected from the two middle ridges in each plot to determine total tuber yield $(\mathrm{kg}$

Fayoum J. Agric. Res. \& Dev., Vol.25, No.1, January, 2011 
fed $^{-1}$ ), total carbohydrates $\%$ were determined according to A.O.A.C. (1990). The nutrient $\mathrm{N}, \mathrm{P}, \mathrm{K}, \mathrm{Fe}, \mathrm{Mn}, \mathrm{Zn}, \mathrm{Cu}$ and $\mathrm{B}$ contents were determined in potato shoots and tuber according to Jackson (1973). At the same times, soil samples were collected from each plot, air died, ground, passed through $2 \mathrm{~mm}$ sieve to obtain the fine earth, and then were subjected to determine soil available nutrient contents. Available nitrogen was extracted by $\mathrm{KCl}$ solution of $2 \mathrm{M}$ and determined by using Technician Auto Analyzer according to Markus et al. (1982). Available P, K and micronutrients (i.e., $\mathrm{Fe}, \mathrm{Mn}, \mathrm{Zn}, \mathrm{Cu}$ and $\mathrm{B}$ ) were extracted by ammonium bicarbonate (AB-DTPA) according to Soltanpour and Schwab (1977), and then P content was determined using the standard method outlined by Jackson (1973). Meanwhile, $\mathrm{K}$ was measured by using Flame Photometer and available micronutrient contents were measured by using Atomic Absorption Spectrophotometer. The obtained data of an average for the tested two growing seasons were statistically analyzed using the using L.S.D. at 0.05 as described by Snedecor and Cochran (1980).

\section{RESULTS AND DISCUSSION:}

\section{General view on the characteristics of the experimental soil:}

Data presented in Table (1) showed that the experimental soil is characterized by sandy in texture, non-saline and non-sodic, well drained and non-calcareous in nature. The studied soil is mainly encompassing the siliceous desert formation as a parent material, where it is developed on the desert formations of the Western Desert of Egypt under a climatic condition characterized by long hot rainless summer and short mild winter, with scare amounts of rainfall.

\section{a. Soil taxonomy:}

Soil taxonomic unit is identified at the family level according to Soil Survey Staff (USDA, 2010) as Typic Torripsamments, siliceous, thermic.

\section{b. Soil evaluation for agricultural irrigated land:}

Also, according to parametric system undertaken by Sys and Verheye (1978), the intensity degrees of soil limitations and suitability categories for the studied soil were calculated and presented in Table (3). It is cleared from data obtained that soil texture and gypsum are the most effective limitations for soil productivity, with corresponding intensity degree lies in very severe and slight, i.e., rating $<40$ and $>90$, respectively. Also, the suitability classes of the studied soil could be identified as a marginally suitable class $\left(\mathrm{S}_{3} \mathrm{~s}_{1} \mathrm{~S}_{4}\right)$ for both current and potential conditions.

Table (3): Soil limitations and rating indices for the evaluation of the studied soil.

\begin{tabular}{|c|c|c|c|c|c|c|c|c|c|c|}
\hline \multirow[b]{2}{*}{ 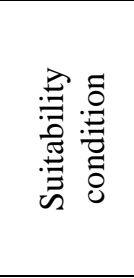 } & \multirow[b]{2}{*}{ 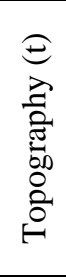 } & \multirow[b]{2}{*}{$\begin{array}{l}\widehat{3} \\
0 \\
0 \\
0 \\
0 \\
0 \\
3\end{array}$} & \multicolumn{4}{|c|}{$\mathrm{S}$} & \multirow[b]{2}{*}{ 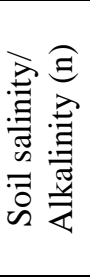 } & \multirow[b]{2}{*}{ 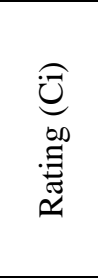 } & \multirow[b]{2}{*}{ 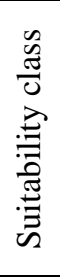 } & \multirow[b]{2}{*}{ 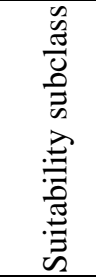 } \\
\hline & & & 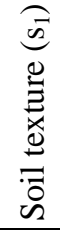 & 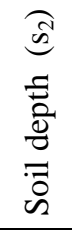 & $\bigcup_{\tilde{U}}^{\infty} \underset{\infty}{\infty}$ & $\begin{array}{l}\underbrace{f}_{0} \\
\Xi \\
\Xi \\
\underbrace{0}_{0} \\
\overbrace{0}^{n}\end{array}$ & & & & \\
\hline Current & 100 & 100 & 30 & 100 & 100 & 90 & 100 & 27.00 & S3 & $\mathrm{S} 3 \mathrm{~s}_{1} \mathrm{~s}_{4}$ \\
\hline Potential & 100 & 100 & 30 & 100 & 100 & 90 & 100 & 27.00 & S3 & $\mathrm{S} 3 \mathrm{~s}_{1} \mathrm{~s}_{4}$ \\
\hline
\end{tabular}

\section{c. Soil suitability for potato plants:}

Firstly, land suitability for agricultural irrigated soils is the appraisal of specific areas of land from a general point of view without mentioning the specific kind of use. So, soil suitable for a specific crop and unsuitable for another is based

Fayoum J. Agric. Res. \& Dev., Vol.25, No.1, January, 2011 
on evaluating the land for utilization types, which used as guides for the most beneficial use for a specific productivity by replacing a less adapted land utilization type by another promising one, and was applied in this study according to Sys et al. (1993). The evaluation indices of land characteristics are done by rating them and specifying their limitations for certain crops by matching the calculated rating with the crop requirements in different suitability levels as proposed by Sys et al. (1993), as shown in Table (4).

In the studied area, without major land improvements, the crop requirements were matched with the present land qualities for processing the current and potential land suitability of the different land units. This approach enables management of different alternatives for specific utilizations that are adapted to the existing limitations to give maximum output.

Table (4): Soil suitability for cultivation of potato plants.

\begin{tabular}{|c|c|c|c|c|c|c|c|c|c|}
\hline \multirow[b]{2}{*}{ 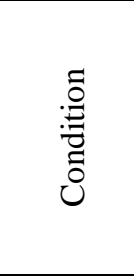 } & \multirow[b]{2}{*}{ 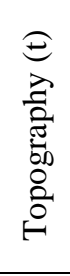 } & \multirow[b]{2}{*}{$\begin{array}{l}\widehat{3} \\
0 \\
0 \\
0 \\
0 \\
0 \\
3\end{array}$} & \multicolumn{4}{|c|}{$\mathrm{S}$} & \multirow[b]{2}{*}{ 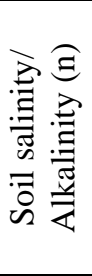 } & \multirow[b]{2}{*}{ 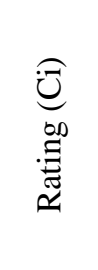 } & \multirow[b]{2}{*}{ 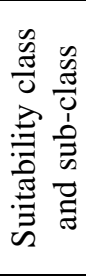 } \\
\hline & & & 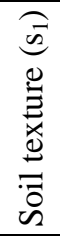 & 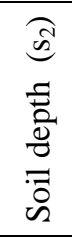 & 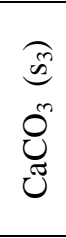 & 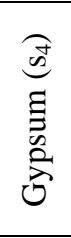 & & & \\
\hline Current & 100 & 100 & 45 & 100 & 100 & 100 & 95 & 42.75 & $\mathrm{~S} 3 \mathrm{~s}_{1} \mathrm{n}$ \\
\hline Potential & 100 & 100 & 45 & 100 & 100 & 100 & 100 & 45.00 & $\mathrm{~S} 3 \mathrm{~s}_{1}$ \\
\hline
\end{tabular}

As for this purpose, the suitability class of the experimental soil, either in the current or potential condition for the cultivation of potato plants is applicable for the main characteristics of the studied area, which are considered regarding land qualities of drainage, salinity and sodicity. Moreover, the resultant adaptations of soil suitability class for cultivating potato plants could be considered as marginally suitable adaptation in the current $\left(\mathrm{S} 3 \mathrm{~s}_{1} \mathrm{n}\right)$ and potential $\left(\mathrm{S}_{3} \mathrm{~s}_{1}\right)$ conditions, with a rating index of 42.75-45.00. Also, soil texture $\left(\mathrm{s}_{1}\right)$ and salinity/alkalinity (n) represent the main limitations for soil productivity in the current condition, and $s_{1}$ in the potential one with an intensity degree of severe $(<40 \%)$ for $s_{1}$ and slight $(>$ $90 \%$ ) for $\mathrm{n}$. It is noteworthy to mention that $\mathrm{s}_{1}$ will be remained as permanent soil limitations.

The aforementioned soil characteristics are evident that the main mechanical constituent of the studied sandy soil is the sand fraction which is not partially capable to retain neither soil moisture nor nutrients for either growing plants or organisms. Moreover, it is poor not only in the nutrient-bearing minerals, but also in nutrient-bearing minerals and organic matter that represent storehouse of the essential nutrients in soil. Thus, under these severe conditions (i.e., inadequate water-nutrients retention), the productivity of different grown crops tends to decrease markedly. Consequently, nutrients disorders in these soils are the most limiting factor to crop production, second only to moisture stress.

Because the conflicting opinions reported on fertilization system and soil moisture regime as related to different crops, especially those are grown on a sandy soil, the current work has been conducted to know farther information about the influence of some local natural nutrient sources, i.e., organic manure and rock phosphate as well as bio-fertilizer of $\mathrm{N}_{2}$-fixer and P-dissolving bacteria on both soil moisture-nutrients retained and biological activity as well as vegetative growth,

Fayoum J. Agric. Res. \& Dev., Vol.25, No.1, January, 2011 
yield and tuber quality of potato as a test crop grown on a newly reclaimed sandy soil.

II. Soil available nutrients status and some vegetative growth parameter as affected by the applied treatments: a. Soil available nutrients status:

There is no doubt that the available nutrients in the experimental soil will be increased due to applying some local natural nutrient sources, i.e., organic compost and rock phosphate enriched in many of macro and micronutrients. Data presented in Table (5) revealed that the available nutrient contents in the soil plots tended to increase during the maximum vegetative growth stage with a clearly difference according to the nature and rate of the applied organic (organic compost) and biofertilizers $\left(\mathrm{N}_{2}\right.$-fixer bacteria of Cyanobacteria and P-dissolving bacteria of Bacillus megatherium var. phosphaticum) a as well as amino acids.

On the other hand, the obtained results of applied amino acids as foliar spray on plants showed a very slightly increase in soil content of the studied available nutrients, with insignificantly effect between untreated and treated soil plots. That was true, since Szajdak et al. (2004) stated the application of amino acids as foliar use is based on its requirement by plants in general and at critical stage of growth in particular plant absorb amino acids through stomas and is proportionate to environment temperature. Also, amino acids are supplied to plant by incorporating them into the soil, where it helps in improving the microflora facilating the thereby enhancing the assimilation of nutrients.

Table (5): Soil available nutrient contents as affected by the applied treatments.

\begin{tabular}{|c|c|c|c|c|c|c|c|c|c|}
\hline \multicolumn{2}{|c|}{ Treatment } & \multicolumn{8}{|c|}{ Soil available macro and micronutrients $\left(\mathrm{mg} \mathrm{kg}^{-1}\right.$ soil) } \\
\hline \multirow{2}{*}{$\begin{array}{c}\text { Bio- } \\
\text { organic }\end{array}$} & \multirow{2}{*}{$\begin{array}{c}\text { Amino } \\
\text { acids }\end{array}$} & \multicolumn{3}{|c|}{ Macronutrients } & \multicolumn{5}{|c|}{ Micronutrients } \\
\hline & & $\mathrm{N}$ & $\mathrm{P}$ & $\mathrm{K}$ & $\mathrm{Fe}$ & $\mathrm{Mn}$ & $\mathrm{Zn}$ & $\mathrm{Cu}$ & $\mathrm{B}$ \\
\hline \multicolumn{2}{|c|}{ Initial soil state } & 21.34 & 3.65 & 54.70 & 4.30 & 0.84 & 0.62 & 0.47 & 0.38 \\
\hline \multirow{2}{*}{$\mathrm{C}_{1}$} & $\mathrm{~A}_{0}$ & 39.15 & 6.20 & 76.85 & 5.98 & 1.75 & 1.55 & 1.35 & 0.70 \\
\hline & $\mathrm{A}_{1}$ & 41.80 & 6.35 & 77.35 & 6.25 & 1.84 & 1.60 & 1.40 & 0.74 \\
\hline \multirow{2}{*}{$\mathrm{C}_{2}$} & $\mathrm{~A}_{0}$ & 44.30 & 6.91 & 85.40 & 6.71 & 1.98 & 1.70 & 1.49 & 0.80 \\
\hline & $\mathrm{A}_{1}$ & 47.63 & 7.05 & 86.10 & 6.94 & 2.04 & 1.76 & 1.52 & 0.85 \\
\hline \multirow{2}{*}{$\mathrm{C}_{3}$} & $\mathrm{~A}_{0}$ & 34.00 & 5.40 & 67.65 & 5.30 & 1.56 & 1.32 & 1.16 & 0.62 \\
\hline & $\mathrm{A}_{1}$ & 36.95 & 5.54 & 68.00 & 5.50 & 1.63 & 1.38 & 1.20 & 0.65 \\
\hline \multirow{2}{*}{$\mathrm{C}_{4}$} & $\mathrm{~A}_{0}$ & 30.05 & 4.85 & 60.35 & 4.72 & 1.40 & 1.20 & 1.05 & 0.57 \\
\hline & $\mathrm{A}_{1}$ & 32.74 & 5.00 & 61.70 & 4.90 & 1.45 & 1.25 & 1.09 & 0.60 \\
\hline \multicolumn{10}{|c|}{ Statistical analysis } \\
\hline \multirow{3}{*}{$\begin{array}{l}\text { L.S.D. } \\
\text { at } 0.05\end{array}$} & $\mathrm{C}$ & 1.71 & 0.37 & 2.81 & 0.65 & 0.12 & 0.11 & 0.13 & 0.05 \\
\hline & $\mathrm{A}$ & 2.43 & 0.24 & 1.99 & 0.70 & 0.22 & 0.21 & 0.09 & 0.05 \\
\hline & $\mathrm{C} \times \mathrm{A}$ & 1.42 & 0.19 & 2.01 & 0.41 & 0.30 & 0.13 & 0.09 & 0.04 \\
\hline
\end{tabular}

$\mathrm{C}_{1}=$ Full dose of organic compost, $\mathrm{C}_{2}=\left(3 / 4 \mathrm{C}_{1}+\mathrm{N}_{2}\right.$-fixer and P-dissolving bacteria + rock phosphate $+\mathrm{K}$ sulphate), $\mathrm{C}_{3}\left(1 / 2 \mathrm{C}_{1}+\mathrm{N}_{2}\right.$-fixer and P-dissolving bacteria + rock phosphate $+\mathrm{K}$-sulphate $), \mathrm{C}_{4}\left(1 / 4 \mathrm{C}_{1}+\right.$ $\mathrm{N}_{2}$-fixer and P-dissolving bacteria + rock phosphate $+\mathrm{K}$-sulphate), $\mathrm{A}_{0}=$ Untreated with amino acids, $\mathrm{A}_{1}=$ Treated with amino acids as foliar spray.

Data in Table (5) showed also an obvious clear response for available nutrient contents to the applied treatments, particularly the triple combined one $\left(\mathrm{C}_{2}\right)$, i.e., organic compost + biofertilizer $\left(\mathrm{N}_{2}\right.$-fixer and P-dissolving bacteria $)+\mathrm{P}-$ $\mathrm{K}$-inorganic source (rock phosphate and K-sulphate). Generally, the beneficial effect of the applied treatments, especially those included organic manure, on an increment of available nutrient contents in the soil may be attributed to their slow

Fayoum J. Agric. Res. \& Dev., Vol.25, No.1, January, 2011 
release during the decomposition and mineralization processes as well as minimizing their possible lose by leaching throughout the studied relatively coarse texture soil (Mohammed, 2004). Moreover, the integrated role of applied organic manure plus bio-fertilizer was more pronounced for nutrients availability in the soil, may be the released active organic acids during microbial activity that enhancing the solubilization of nutrient from the native and added sources. Also, the effective role of the applied treatments was commonly achieved by lowering soil $\mathrm{pH}$, and in turn encouraging the availability of plant essential nutrients, especially phosphorus and micronutrients that forming organo-metalic compounds of chelated micronutrients. The later represent the next superior available forms, this is due to a higher portion of these compounds still in maintained active ones for extended period. In addition, the beneficial effect of applied organic manure was more attributed to its enrichment in the organic substances which have ability to improve soil-moisture regime and adsorbed mineral nutrients as a storehouse in more mobile or available forms to uptake by plant roots.

In here, the sequence of the superiority for the applied treatments could be taken an ascending order of $\mathrm{C}_{2}>\mathrm{C}_{1}>\mathrm{C}_{3}>\mathrm{C}_{4}$. Generally, the superiority of combined effects of applied organic manure, bio-fertilizer and $\mathrm{P}-\mathrm{K}$-inorganic source treatment $\left(\mathrm{C}_{2}\right)$ for the pronounced increase in soil available nutrient contents and biological conditions that enhancing nutrients uptake by plants could be interpreted as follows:

i. Organic compost decomposition tends to accelerate in the presence of microbial media of bio-fertilizer, and in turn produces active organic and inorganic acids that led to decrease soil $\mathrm{pH}$ as well as they have used to chelate metals (Fe, $\mathrm{Mn}, \mathrm{Zn}$ and $\mathrm{Cu}$ ). These chelated metal cations are not sensitive to the restriction or the adverseable effects of alkaline side, consequently they are found as strategic storehouse in organo-metalic compounds that are more suitable for uptake by plant roots.

ii. The effective role of microbial activity to increase soil content of $\mathrm{N}$ and $\mathrm{P}$ particularly in a combination with organic compost as an energy sources, could be interpreted according to many opinions outlined by El-Fayoumy and Radwan (2002) and Ashmaye et al. (2008) who reported that many strains produce several phytohormones (i.e., indole acetic acid and cytokinins) and organic acids. Such products reduce the adverseable effect of soil conditions, and then simultaneously improving soil nutrients status, i.e., increasing available nutrient contents due to organic compost represents a storehouse of essential nutrients as well as enhancing their availability and mobility vs their possible losses by the leaching process through irrigation fractions in such a skeletal sandy soil.

In this concern, Sharma and Mittra (1991) stated also that organic materials reduce nitrogen losses and conserve soil by forming organo-mineral complexes. Pointing the available phosphorous content, the pronounced increases could be attributed to mineralization of organic $\mathrm{P}$, solubilization action of certain organic acids and displacement of phosphate with organic anions. In this respect, (AbouHussein et al., 2002) found that micro-organisms are characterized with their ability to mobilize the unavailable forms of nutrients to available form thus increased the soil available such as N, P and K. Moreover, Agrower's (1999)

Fayoum J. Agric. Res. \& Dev., Vol.25, No.1, January, 2011 
reported that applied bio-organic manure plays a dual role for increasing soil cation exchange capacity, and then increased soil capacity to retain more available contents of certain nutrients as well as help neutralize and buffer soil $\mathrm{pH}$.

\section{b. Some vegetative growth parameters:}

It is evident that the vegetative growth parameters, i.e., plant height, Nos. of leaves and branches plant ${ }^{-1}$ and shoots dry matter plant ${ }^{-1}$ after 70 days from planting are significantly increased in the treated soils, with a superiority sequence for the applied treatments as shown in an ascending order of $\mathrm{C}_{2}>\mathrm{C}_{1}>\mathrm{C}_{3}>\mathrm{C}_{4}$. That was true, since the greatest values of the studied vegetative growth parameters were more attributed with the vital role of the combined treatment of bio-organic manures of $\mathrm{C}_{2}$ that caused a best amelioration process for soil physico-chemical and biological characteristics as well as soil nutritional status, which in turn positively reflected on plant growth parameters.

Table (6): Some vegetative growth parameters as affected by the applied treatments.

\begin{tabular}{|c|c|c|c|c|c|}
\hline \multicolumn{2}{|c|}{ Treatment } & \multirow[b]{2}{*}{ Plant height $(\mathrm{cm})$} & \multirow[b]{2}{*}{$\begin{array}{l}\text { Leaf number } \\
\text { plant }^{-1}\end{array}$} & \multirow[b]{2}{*}{$\begin{array}{l}\text { Branches number } \\
\text { plant }^{-1}\end{array}$} & \multirow[b]{2}{*}{$\begin{array}{c}\text { Shoots dry matter } \\
\left(\mathrm{g} \text { plant }^{-1}\right)\end{array}$} \\
\hline $\begin{array}{c}\text { Bio- } \\
\text { organic }\end{array}$ & $\begin{array}{l}\text { Amino } \\
\text { acids }\end{array}$ & & & & \\
\hline \multirow{2}{*}{$\mathrm{C}_{1}$} & $\mathrm{~A}_{0}$ & 66.95 & 15.90 & 4.45 & 34.54 \\
\hline & $\mathrm{A}_{1}$ & 69.23 & 17.45 & 4.73 & 36.27 \\
\hline \multirow{2}{*}{$\mathrm{C}_{2}$} & $\mathrm{~A}_{0}$ & 70.72 & 17.64 & 4.56 & 36.28 \\
\hline & $\mathrm{A}_{1}$ & 76.40 & 18.72 & 5.76 & 39.74 \\
\hline \multirow{2}{*}{$\mathrm{C}_{3}$} & $\mathrm{~A}_{0}$ & 64.35 & 15.19 & 4.90 & 31.86 \\
\hline & $\mathrm{A}_{1}$ & 66.50 & 16.28 & 4.38 & 34.10 \\
\hline \multirow{2}{*}{$\mathrm{C}_{4}$} & $\mathrm{~A}_{0}$ & 54.75 & 13.75 & 3.25 & 28.64 \\
\hline & $\mathrm{A}_{1}$ & 56.84 & 15.87 & 3.74 & 30.55 \\
\hline \multicolumn{6}{|c|}{ Statistical analysis } \\
\hline \multirow{3}{*}{$\begin{array}{l}\text { L.S.D. } \\
\text { at } 0.05\end{array}$} & $\mathrm{C}$ & 1.47 & 0.39 & 0.06 & 0.48 \\
\hline & $\mathrm{A}$ & 1.54 & 0.32 & 0.15 & 0.75 \\
\hline & $\mathrm{C} \times \mathrm{A}$ & 2.24 & 0.45 & 0.24 & 1.07 \\
\hline
\end{tabular}

$\mathrm{C}_{1}=$ Full dose of organic compost, $\mathrm{C}_{2}=\left(3 / 4 \mathrm{C}_{1}+\mathrm{N}_{2}\right.$-fixer and P-dissolving bacteria + rock phosphate $+\mathrm{K}$ sulphate), $\mathrm{C}_{3}\left(1 / 2 \mathrm{C}_{1}+\mathrm{N}_{2}\right.$-fixer and P-dissolving bacteria + rock phosphate $+\mathrm{K}$-sulphate $), \mathrm{C}_{4}\left(1 / 4 \mathrm{C}_{1}+\right.$ $\mathrm{N}_{2}$-fixer and P-dissolving bacteria + rock phosphate + K-sulphate), $\mathrm{A}_{0}=$ Untreated with amino acids, $\mathrm{A}_{1}=$ Treated with amino acids as foliar spray.

Irrespective the favourable effect of this treatment $\left(\mathrm{C}_{2}\right)$, besides higher in a symbiotic $\mathrm{N}_{2}$-fixar and P-dissolving bacteria, may be also due to the production of growth regulators such as auxins, cytokinins and gibberellins, which affect the production of root biomass and nutrients uptake (Massoud et al., 2008).

III. Potato shoots nutrient contents as affected by the applied treatments:

As obtained in Table (7), nitrogen content in potato shoots was significantly increased by the applied treatments, i.e., either full organic compost dose as a solely treatment or plus supplementary with a partial substitution by tuber bioinoculation $\left(\mathrm{N}_{2}\right.$-fixer bacteria of Cyanobacteria, rock phosphate $+\mathrm{P}$-dissolving bacteria of Bacillus megatherium var. phosphaticum) and potassium sulphate of $\mathrm{K}_{2} \mathrm{O} 48 \%$. These increases in shoot nutrient contents were maximized as a result of applied amino acids as a foliar spray on plant shoots, may be attributed to the high capacity and response of both the experimental soil and grown plants to receive the

Fayoum J. Agric. Res. \& Dev., Vol.25, No.1, January, 2011 
applied treatments of local natural organic manure and a partial biofertilizer plus some P-K-inorganic source in building metabolites. Such favourable effects reflected on more vigorous plant growth and rooting system, which in turn contributes to increase nitrogen content in plant organs. So, the sequence of the superiority for the applied treatments could be arranged in an ascending order of $\mathrm{C}_{2}$ $>\mathrm{C}_{1}>\mathrm{C}_{3}>\mathrm{C}_{4}$. These results are in accordance with those obtained by AbouHussein (2005), Selim and El-Mancy (2007) and El-Shazly (2008).

Concerning phosphorous content in potato shoots, data in Table (7) revealed that, regardless biofertilizer (P-dissolving bacteria of Bacillus megatherium var. phosphaticum + rock phosphate), there was a significant increase in $\mathrm{P}$ content in potato shoots as a result of applying the different treatments, with an ascending order of $\mathrm{C}_{2}>\mathrm{C}_{1}>\mathrm{C}_{3}>\mathrm{C}_{4}$. That was true, since $\mathrm{C}_{2}$ represents a triple combined effect of applied (organic manure + bio-fertilizer $+\mathrm{P}-\mathrm{K}$-inorganic source) that caused a pronounced increase $\mathrm{P}$ content in potato shoots as well as the other studied nutrient contents. It is clearly that the pronounced differences of $\mathrm{P}$ contents in potato shoots were more attributed to the nature of the applied treatments during the tested two seasons. Thus, it can be concluded that, biofertilizer plus rock phosphate represent an inorganic source for P-released and other nutrients through the natural bio-processes of solubilizing phosphorus, and stimulating plant growth through the synthesis of growth promoting substances play an important role for increasing their contents in potato shoots.

Table (7): Potato shoots nutrient contents as affected by the applied treatments.

\begin{tabular}{|c|c|c|c|c|c|c|c|c|c|}
\hline \multicolumn{2}{|c|}{ Treatment } & \multicolumn{3}{|c|}{ Macronutrients $\%$} & \multicolumn{5}{c|}{ Micronutrients $\left(\mathrm{mg} \mathrm{kg}^{-1}\right)$} \\
\hline $\begin{array}{c}\text { Bio- } \\
\text { organic }\end{array}$ & $\begin{array}{c}\text { Amino } \\
\text { acids }\end{array}$ & $\mathrm{N}$ & $\mathrm{P}$ & $\mathrm{K}$ & $\mathrm{Fe}$ & $\mathrm{Mn}$ & $\mathrm{Zn}$ & $\mathrm{Cu}$ & $\mathrm{B}$ \\
\hline \multirow{2}{*}{$\mathrm{C}_{1}$} & $\mathrm{~A}_{0}$ & 3.00 & 0.61 & 3.22 & 275.40 & 102.41 & 65.90 & 25.50 & 16.30 \\
\cline { 2 - 12 } & $\mathrm{A}_{1}$ & 3.59 & 0.83 & 3.65 & 334.46 & 125.64 & 71.32 & 30.20 & 19.27 \\
\hline \multirow{2}{*}{$\mathrm{C}_{2}$} & $\mathrm{~A}_{0}$ & 3.35 & 0.76 & 3.60 & 317.50 & 121.52 & 70.94 & 28.96 & 18.21 \\
\cline { 2 - 11 } & $\mathrm{A}_{1}$ & 4.05 & 0.95 & 4.15 & 378.63 & 147.87 & 78.35 & 34.54 & 21.70 \\
\hline \multirow{2}{*}{$\mathrm{C}_{3}$} & $\mathrm{~A}_{0}$ & 2.50 & 0.56 & 2.64 & 230.44 & 89.65 & 59.41 & 21.70 & 13.45 \\
\cline { 2 - 11 } & $\mathrm{A}_{1}$ & 3.05 & 0.75 & 3.09 & 287.36 & 103.59 & 64.50 & 25.68 & 16.31 \\
\hline \multirow{2}{*}{$\mathrm{C}_{4}$} & $\mathrm{~A}_{0}$ & 2.12 & 0.45 & 2.05 & 189.20 & 72.83 & 52.15 & 18.02 & 11.00 \\
\cline { 2 - 10 } & $\mathrm{A}_{1}$ & 2.64 & 0.64 & 2.40 & 236.45 & 87.05 & 49.48 & 22.65 & 14.64 \\
\hline \multirow{2}{*}{$\begin{array}{c}\text { L.S.D. } \\
\text { at 0.05 }\end{array}$} & $\mathrm{C}$ & 0.32 & 0.11 & 0.51 & 30.11 & 11.12 & 2.91 & 1.29 & 1.11 \\
\cline { 2 - 10 } & $\mathrm{C}$ & 0.41 & 0.17 & 0.35 & 11.22 & 9.59 & 1.78 & 2.51 & 1.21 \\
\hline
\end{tabular}

$\mathrm{C}_{1}=$ Full dose of organic compost, $\mathrm{C}_{2}=\left(3 / 4 \mathrm{C}_{1}+\mathrm{N}_{2}\right.$-fixer and P-dissolving bacteria + rock phosphate $+\mathrm{K}$ sulphate), $C_{3}\left(1 / 2 C_{1}+N_{2}\right.$-fixer and P-dissolving bacteria + rock phosphate + K-sulphate $), C_{4}\left(1 / 4 C_{1}+\right.$ $\mathrm{N}_{2}$-fixer and P-dissolving bacteria + rock phosphate + K-sulphate), $\mathrm{A}_{0}=$ Untreated with amino acids, $\mathrm{A}_{1}=$ Treated with amino acids as foliar spray.

Regarding the effect of the applied treatments on potassium content in potato shoots, data in Table (7) showed that applying $\mathrm{C}_{2}$ gained the best value of potassium in potato shoots, may be due to the beneficial soil conditions as previously discussed. Also, the addition of potassium sulphate as an easily $\mathrm{K}$ source plays an effective role for enhancing $\mathrm{K}$ uptake by potato shoots, and in turn increasing $\mathrm{K}$ content in shoots. In addition, the steady release of potassium from the applied organic compost and biofertilizer may be supported K-accumulation in

Fayoum J. Agric. Res. \& Dev., Vol.25, No.1, January, 2011 
the plant tissues. These obtained results are in accordance with those reported by Selim and El-Mancy (2007) and El-Shazly (2008).

Concerning the effect of the applied treatments on the contents of Fe, Mn, $\mathrm{Zn}, \mathrm{Cu}$ and $\mathrm{B}$ in potato shoots, data presented in Table (7) indicated a significantly increased in potato shoots content of these micronutrients. These results may be due to that the applied organic compost is considered a storehouse for the slow released nutrients, with a superiority for the treatment of $\mathrm{C}_{2}$ that represents a triple combined effect of applied (organic manure + bio-fertilizer + P-K-inorganic source), and in turn it causes a pronounced increase in potato shoots content of the tested micronutrients. It is clearly that the pronounced differences of the studied micronutrient contents in potato shoots were more attributed to the nature of the applied treatments during the two successive seasons. These nutrient contents were maximized due to spraying amino acids on the potato plants, where the sprayed plants gained the best values for the micronutrients under study.

In contrast, the use of bio-organic manure increased the organic matter content of the experimental soil that is maintained good yield (Santosh-Sahay, 2004). Thus, a great attention has been directed towards the application of bioorganic farming to avoid the heavy use of agrochemicals that result in enormous environmental troubles (Abd-El-Ghany, 2007). Also, it seems reasonable to conclude that biofertilization significantly increased crop yield and nutrient contents of plant tissues (Ghosh $\boldsymbol{e t}$ al., 2000 and Shehata et al., 2003).

$I V$. Potato tuber yield and quality as affected by the applied treatments:

Potato requires adequate nitrogen to produce high quality tubers and yield. In organic system, nitrogen $(\mathrm{N})$ enters the soil in the form of crop residue and soil amendment (i.e., organic manure and especially product). Much of the $\mathrm{N}$ added to the soil is held in an organic form not immediately available for crop uptake, however, only a small fraction of soil organic $\mathrm{N}$ is released in plant available form throughout a bio-process called N-mineralization.

Data in Table (8) indicated that the interaction effect of compost and biofertilizer caused significant increases in total potato tubers yield and quality. The greatest potato tuber yield of 22.35 ton/fed was recorded with plants supplied by a triple combined treatment of $\mathrm{C}_{2}$ (organic manure + bio-fertilizer $+\mathrm{P}-\mathrm{K}$ inorganic source) in combination with amino acids as foliar spray on potato plants. The increase in potato tuber yield in this script could be attributed to physical processes including growth and nutrients supply. These obtained results are in agreement with those reported by Mohanty and Das (2002).

In general, the obtained data concerning the response of potato tuber yield to the applied amino acids are in good accordance with that recorded by Mikhtizal (2004) and Khan et al. (2005). This beneficial effect may be due to its role in plant growth that enhanced carbohydrates movement from plant roots to the shoots and accumulated as a storehouse in tuber tissues (Hewedy, 2000). That is expected in case of the experimental sandy soil, however, the beneficial effect of applied bioorganic manure on potato tuber yield might be related to improve soil physical, chemical and biological conditions. The favourable effect of the later is more attributed to such bio-organic manure provided energy for microorganism activity, and then increased the released nutrients supply and improved their mobility and uptake by plant organs (El-Shazly, 2008).

Fayoum J. Agric. Res. \& Dev., Vol.25, No.1, January, 2011 
Concerning total carbohydrates content in potato tuber, results illustrated in Table (8) indicated that the percentage of total carbohydrates in tuber dry matter was significantly increased with applying the tested treatments of bio-organic manure and P-K-inorganic source in combination with amino acids as foliar spray. These results are confirmed by the positive correlation between dry matter and total carbohydrates of potato tubers. In the same trend, Abou-Hussein et al. (2002) and Makaraviciute (2003) suggested that tuber carbohydrate content was increased with organic manure application. Moreover, these results are in agreement with those obtained by Sarhan et al. (2004). Similar observation was obtained with dry matter \% in potato tubers, where Abou-Hussien et al. (2002a and b) demonstrated that applying biofertilizer to the soil or inoculated with tubers, increased dry matter content, total carbohydrates and total yield of potato.

Table (8): Potato tuber yield and quality as affected by the applied treatments.

\begin{tabular}{|c|c|c|c|c|c|}
\hline \multicolumn{2}{|c|}{ Treatment } & \multirow{2}{*}{$\begin{array}{l}\text { Potato tuber yield } \\
\quad\left(\text { ton } \mathrm{fed}^{-1}\right)\end{array}$} & \multicolumn{3}{|c|}{ Potato tuber quality parameters } \\
\hline $\begin{array}{l}\text { Bio- } \\
\text { organic }\end{array}$ & $\begin{array}{l}\text { Amino } \\
\text { acids }\end{array}$ & & $\begin{array}{c}\text { Carbohydrates } \\
\%\end{array}$ & $\begin{array}{c}\text { Crude protein } \\
\%\end{array}$ & $\begin{array}{c}\text { Dry matter } \\
\%\end{array}$ \\
\hline \multirow{2}{*}{$\mathrm{C}_{1}$} & $\mathrm{~A}_{0}$ & 17.50 & 43.94 & 14.75 & 16.10 \\
\hline & $\mathrm{A}_{1}$ & 20.81 & 48.75 & 16.87 & 19.50 \\
\hline \multirow{2}{*}{$\mathrm{C}_{2}$} & $\mathrm{~A}_{0}$ & 19.46 & 47.29 & 15.44 & 18.78 \\
\hline & $\mathrm{A}_{1}$ & 22.35 & 52.48 & 17.63 & 21.15 \\
\hline \multirow{2}{*}{$\mathrm{C}_{3}$} & $\mathrm{~A}_{0}$ & 15.82 & 39.15 & 13.80 & 14.95 \\
\hline & $\mathrm{A}_{1}$ & 18.50 & 44.92 & 15.36 & 16.62 \\
\hline \multirow{2}{*}{$\mathrm{C}_{4}$} & $\mathrm{~A}_{0}$ & 12.74 & 35.85 & 13.38 & 12.00 \\
\hline & $\mathrm{A}_{1}$ & 16.10 & 41.75 & 14.50 & 14.05 \\
\hline \multicolumn{6}{|c|}{ Statistical analysis } \\
\hline \multirow{3}{*}{$\begin{array}{l}\text { L.S.D. } \\
\text { at } 0.05\end{array}$} & $\mathrm{C}$ & 0.81 & 2.91 & 0.65 & 1.90 \\
\hline & $\mathrm{A}$ & 0.74 & 1.39 & 0.52 & 1.11 \\
\hline & $\mathrm{C} \times \mathrm{A}$ & 0.68 & 1.73 & 0.71 & 1.13 \\
\hline
\end{tabular}

$\mathrm{C}_{1}=$ Full dose of organic compost, $\mathrm{C}_{2}=\left(3 / 4 \mathrm{C}_{1}+\mathrm{N}_{2}\right.$-fixer and P-dissolving bacteria + rock phosphate $+\mathrm{K}$ sulphate), $\mathrm{C}_{3}\left(1 / 2 \mathrm{C}_{1}+\mathrm{N}_{2}\right.$-fixer and P-dissolving bacteria + rock phosphate $+\mathrm{K}$-sulphate $), \mathrm{C}_{4}\left(1 / 4 \mathrm{C}_{1}+\right.$ $\mathrm{N}_{2}$-fixer and P-dissolving bacteria + rock phosphate $+\mathrm{K}$-sulphate), $\mathrm{A}_{0}=$ Untreated with amino acids, $\mathrm{A}_{1}=$ Treated with amino acids as foliar spray.

Regarding crude protein content $\%$ in potato tubers, data in Table (8) indicated the positive effect of the interaction between bio-organic manure and amino acids on protein $\%$, which showed a greatest content of $17.63 \%$ at the treatment of $\mathrm{C}_{2}$ (3/4 of full dose of organic compos, supplementary with a partial substitution by tuber bio-inoculation with $\mathrm{N}_{2}$-fixer bacteria of Cyanobacteria, rock phosphate + P-dissolving bacteria of Bacillus megatherium var. phosphaticum and potassium sulphate of $\mathrm{K}_{2} \mathrm{O} 48 \%$ in combination with amino acids as a foliar spray. Such positive effect for increasing protein $\%$ in potato tuber was also observed by Talley (1983) and Sirkuman \& Ockerman (1990).

\section{$V$. Potato tuber nutrient contents as affected by the applied treatments:}

As expected, the magnitude of available nutrient contents in the experimental soil plots was positively reflected on the nutrients uptake and accumulated in potato tuber tissues. Moreover, data presented in Table (9) showed a parallel and similar trend for the contents of $\mathrm{N}, \mathrm{P}, \mathrm{K}, \mathrm{N}, \mathrm{P}, \mathrm{K}, \mathrm{Fe}, \mathrm{Mn}, \mathrm{Zn}, \mathrm{Cu}$ and $\mathrm{B}$ in potato tubers to those of uptake and accumulated in potato shoot tissues. However, there was a progressively increased in these nutrients with applying the tested treatments, particularly in combination with amino acids as foliar spray. Also, nutrient contents

Fayoum J. Agric. Res. \& Dev., Vol.25, No.1, January, 2011 
in potato tubers exhibited widely variations according to the applied treatments, where the obtained values of increases followed an order of $\mathrm{C}_{2}>\mathrm{C}_{1}>\mathrm{C}_{3}>\mathrm{C}_{4}$. In contrast, the tuber bio-inoculation $\left(\mathrm{N}_{2}\right.$-fixer bacteria of Cyanobacteria, rock phosphate + P-dissolving bacteria of Bacillus megatherium var. phosphaticum) and potassium sulphate of $\mathrm{K}_{2} \mathrm{O} 48 \%$ in combination with sprayed amino acids supported the pronounced increases of the studied nutrients in potato tubers, especially in potato plants grown on the experimental sandy soil that is poorer in essential plant nutrients as mentioned before.

Table (9): Potato tubers nutrient contents as affected by the applied treatments.

\begin{tabular}{|c|c|c|c|c|c|c|c|c|c|}
\hline \multicolumn{2}{|c|}{ Treatment } & \multicolumn{3}{|c|}{ Macronutrients \% } & \multicolumn{5}{c|}{ Micronutrients $\left(\mathrm{mg} \mathrm{kg}^{-1}\right)$} \\
\hline $\begin{array}{c}\text { Bio- } \\
\text { organic }\end{array}$ & $\begin{array}{c}\text { Amino } \\
\text { acids }\end{array}$ & $\mathrm{N}$ & $\mathrm{P}$ & $\mathrm{K}$ & $\mathrm{Fe}$ & $\mathrm{Mn}$ & $\mathrm{Zn}$ & $\mathrm{Cu}$ & $\mathrm{B}$ \\
\hline \multirow{2}{*}{$\mathrm{C}_{1}$} & $\mathrm{~A}_{0}$ & 2.26 & 0.297 & 2.84 & 230.93 & 101.25 & 47.76 & 21.03 & 14.45 \\
\cline { 2 - 12 } & $\mathrm{A}_{1}$ & 2.50 & 0.325 & 2.98 & 269.45 & 116.91 & 59.52 & 25.85 & 16.29 \\
\hline \multirow{2}{*}{$\mathrm{C}_{2}$} & $\mathrm{~A}_{0}$ & 2.47 & 0.320 & 3.17 & 245.16 & 117.27 & 53.35 & 24.71 & 15.03 \\
\cline { 2 - 11 } & $\mathrm{A}_{1}$ & 2.82 & 0.376 & 3.45 & 295.84 & 130.25 & 67.90 & 29.46 & 18.35 \\
\hline \multirow{2}{*}{$\mathrm{C}_{3}$} & $\mathrm{~A}_{0}$ & 2.02 & 0.232 & 2.42 & 221.51 & 94.90 & 41.86 & 17.87 & 13.75 \\
\cline { 2 - 11 } & $\mathrm{A}_{1}$ & 2.36 & 0.278 & 2.56 & 237.08 & 103.84 & 53.55 & 21.85 & 15.27 \\
\hline \multirow{2}{*}{$\mathrm{C}_{4}$} & $\mathrm{~A}_{0}$ & 1.94 & 0.186 & 2.01 & 205.20 & 87.73 & 38.15 & 14.02 & 12.00 \\
\cline { 2 - 11 } & $\mathrm{A}_{1}$ & 2.15 & 0.215 & 2.23 & 219.45 & 95.05 & 47.78 & 18.65 & 13.96 \\
\hline \multirow{2}{*}{$\begin{array}{c}\text { L.S.D. } \\
\text { at 0.05 }\end{array}$} & $\mathrm{C}$ & 0.11 & 0.04 & 0.31 & 8.93 & 2.71 & 3.21 & 1.73 & 0.39 \\
\cline { 2 - 10 } & $\mathrm{A}$ & 0.17 & 0.05 & 0.11 & 4.24 & 1.79 & 2.97 & 2.39 & 0.24 \\
\cline { 2 - 9 } & $\mathrm{C} \mathrm{A}$ & 0.27 & 0.03 & 0.13 & 7.88 & 3.21 & 3.35 & 2.01 & 0.78 \\
\hline
\end{tabular}

$\mathrm{C}_{1}=$ Full dose of organic compost, $\mathrm{C}_{2}=\left(3 / 4 \mathrm{C}_{1}+\mathrm{N}_{2}\right.$-fixer and P-dissolving bacteria + rock phosphate $+\mathrm{K}$ sulphate), $\mathrm{C}_{3}\left(1 / 2 \mathrm{C}_{1}+\mathrm{N}_{2}\right.$-fixer and P-dissolving bacteria + rock phosphate $+\mathrm{K}$-sulphate $), \mathrm{C}_{4}\left(1 / 4 \mathrm{C}_{1}+\right.$ $\mathrm{N}_{2}$-fixer and P-dissolving bacteria + rock phosphate $+\mathrm{K}$-sulphate), $\mathrm{A}_{0}=$ Untreated with amino acids, $\mathrm{A}_{1}=$ Treated with amino acids as foliar spray.

The superior effect of amino acids may be due to their role in assimilation processes of organic and inorganic phosphorus compounds (phospholipids, phosphoproteins and phosphocarbohydrates). Nassar (1997) found that the released micronutrients simultaneously gave an additional enhancing effect in nutrient contents, may be due to the suitable balance between the aforementioned macronutrients, which enable the plants to grow well and to absorb more quantities of $\mathrm{N}, \mathrm{P}$ and $\mathrm{K}$. On this basis, results of the micronutrients content ( $\mathrm{Fe}, \mathrm{Zn}, \mathrm{Mn}, \mathrm{Cu}$ and $\mathrm{B}$ ) in potato tubers showed an increase as a result of applying the tested treatments due to the creation of organo-micronutrient compounds. The significantly response of nutrients contents, i.e., $\mathrm{N}, \mathrm{P}, \mathrm{K}, \mathrm{Fe}, \mathrm{Mn}, \mathrm{Zn}, \mathrm{Cu}$ and $\mathrm{B}$ in potato tubers to bio-inoculation, soil application of organic manure and supplementary with a partial substitution by the natural P-K-source may be due to increased root growth and utilization of nutrients released from decayed organic manure, $\mathrm{N}_{2}$ bio-fixation, P-dissolving bacteria for rock phosphate along the different growth stages enable the grown plants to absorb more nutrients.

These findings are in agreement with those reported by Kloepper (2003) who pointed out that phytohormones producer bacteria causes pronounced increases for plant root elongation by then uptake of more nutrients via the root system, and hence utilization of nutrients as a result of bio-inoculation. This is mainly due to the applied inoculants of bacteria play a dual role by fixation of atmospheric $\mathrm{N}$ and producing antimicrobial agents against deleterious rhizosphere

Fayoum J. Agric. Res. \& Dev., Vol.25, No.1, January, 2011 
bacteria. Also, Lifshutz et al. (1987) reported that bio-inoculation effect includes an increase in immobilization of insoluble nutrients followed by enhancement of uptake by the plants. These results are also in a line of those obtained by Massoud et al. (2004) who reported that inoculation with $\mathrm{N}_{2}$-fixer bacteria increased uptake of $\mathrm{N}, \mathrm{P}, \mathrm{K}, \mathrm{Fe}, \mathrm{Zn}$, and $\mathrm{Mn}$ by plants.

It is noteworthy to mention that the positive effect of biofertilizers and amino acids on potato shoots nutritional constituents is an expected result, since their effect is more attributed to stimulating plant growth through the synthesis of growth promoting substances as well as improving plant dry mater production. Moreover, Abou-Hussein et al. (2002c) pointed out that such natural substances play a fundamental role in converting $\mathrm{P}$ and $\mathrm{K}$ fixed forms to be soluble ready for plant nutrition making the uptake of nutrients by plants more easy. So that, it could be recommended that organic manure, $\mathrm{N}_{2}$-fixer and P-dissolving bacteria strains should be used to face a great problem of either soil nutrients deficient or excessive $\mathrm{N}$-mineral use for the tested potato varieties. Hence, applying such treatments leading to alleviate the hazardous effect of grain chemical pollution and the environmental risks, which negatively effect on the human health.

These results are also in the line with those obtained by Aly (2003) who stated that some bacteria strains are capable to produce some hormones which induces the proliferation roots and root hair that increase nutrient absorbing surfaces as well as produce organic acids, which solublize inorganic and organic forms of mineral elements, and consequently increase plant shoots and crop yield. In addition, such favourable conditions should be enhance continuous bio-fixed nitrogen, P-dissolving and other nutrients as a slow release along the growth stages of potato plants, and in turn to minimize possible nutrients losses by either leaching process or volatilization and rationalize use of $\mathrm{N}$-mineral fertilizers, which represents surplus point for sustainable agriculture system. This approach represents a new strategy in agriculture field that has a long-term positive agronomic value and an effective practice of nutrient management, and in turn affects the country's economy and its development. That is true, since it is not considered only an ideal solution to meet the excessive nitrogenous fertilizers demand, but also reduce the potential hazardous contamination of both surface and natural underground waters.

\section{REFERENCES:}

Abd-El-Ghany, H.M. (2007). Wheat production under water limited sandy soil condition, using Bioorganic fertilizer system. Egypt. J. Agron., 29 (I): 17-27.

Abou Hussein, S.D. (2005). Yield and quality of potato crop as affected by the application rate of potassium and compost in sandy soil. Annals Agric. Sci., Ain Shams Univ., Cairo, 50 (2): 573-586.

Abou Hussein, S.D.; I. El-Oksh; T. El-Shorbagy and A.M. Gomaa (2002). Effect of cattle manure, biofertilizer and reducing mineral fertilizer on nutrient content and yield of potato plant. Egypt. J. Hort., 29 (10): 99-115.

Abou Hussein, S.D.; U.A. El-Bahiry; I. El-Oksh and M.A. Kalafallah (2002). Effect of compost, biofertilizer and chicken manure on nutrient contents and tuber quality of potato crop. Egypt. J. Hort., 29 (1): 117-133.

Abou Hussein, S.D., I.I. El-Oksh, T. El-Shorbagy and U.A. El-Behairy, (2002a). Effect of chicken manure, compost and biofertilizer on vegetative growth tuber characteristics and yield of potato. Egypt. J. Hort., 29 (1): 135-149.

Fayoum J. Agric. Res. \& Dev., Vol.25, No.1, January, 2011 
Abou Hussein, S.D.; U.A. El-Behairy; I.I. El-Oksh and Kalafallah, (2002b). Effect of compost, biofertilizer and chicken manure on nutrient content and tuber quality of potato crops. Egypt. J. Hort., 29 (1): 117-133.

Abou Hussein, S.D.; I.I. El-Oksh; T. El-Shorbagy and A.M. Gomaa (2002c). Effect of cattle manure, biofertilizer and reducing mineral fertilizer on nutrient contents and yield of potato plant, Egypt. J. Hort., 29 (1): 99-115.

Agrower's, G. (1999). Compost Production and Utilization. California Dep. of Food and Agric., Univ. of California, USA.

Aly, Mona M.M. (2003). Biological studies on some associative nitrogen fixing bacteria. M. Sc. Thesis, Fac. of Agric., Cairo Univ., Giza, Egypt.

A.O.A.C. (1990). Association of Official Analytical Chemists, Official Methods of Analysis, $15^{\text {th }}$ (Ed.), Horwitz, W. (Ed.), Washington, DC., USA.

Ashmaye, S.H.; Kh.A. Shaban and M.G. Abd El-Hader (2008). Effect of mineral nitrogen, sulphur, organic and bio-fertilizers on maize productivity in saline soil of Sahl El-Tina. Minufiya, J. Agric. Res., 33 (1): 195-209

Bakry, M.A; M.M. Poraas, and M.M. Abass (2009). Effect of organic and inorganic soil amendments combined with mineral fertilizers on the fertility of calcareous soil and its productivity. Minufia J. agric. Res., 34 (6): 2243-2260.

Black, C.A.; D.D. Evans; J.L. White; L.E. Ensiminger and F.E. Clark (1982). Methods of Soil Analysis. Amer. Soc. Agron Inc., Ser. 9 in Agron., Madison, Wisconsin.

Bull, C.T.; C. Greene; J.B. Hotcon and L. Oberholtzer (2006). Organic agriculture: Innovations in organic marketing, technology and research, Introduction to the Proceedings, Crop Management 17 May 2007.

Cakmakci, R.; D. Donmez; A. Aydin and F. Sahin (2005). Growth promotion of plants by plant growth promoting rhizobacteria under greenhouse and two different field soil conditions. Soil Biol. Biochem., 38: 1482-1487.

Chapman, H.D. and P.F. Pratt (1961). Methods of Analysis for Soils, Plants and Waters. Univ. of California, Riverside, U.S.A.

Cottenie, A.; M. Verloo; L. Kiekns; G. Veighe and R. Camerlynek (1982). Chemical Analysis of Plants and Soils Lab. Analy. and Agroch. St., State Univ., Ghent, Belgium.

Dilfuza, E. (2007). The effect of plant growth promoting bacteria on growth and nutrient uptake of maize in two different soils. Appl. Soil Ecol., 36: 184-189.

Dimitri, C. and L. Oberholtzer (2006). A brief retrospective on the U.S. organic sector; 1997 and 2003, Crop Management, 17 May 2007.

El-Banna, E.N.; E.M. Awad; H.M. Ramadan and M.R. Mohamed (2001). Effect of bio-organic fertilization in different seasons on growth, yield and tuber quality of potato (Solanum tuberosum L.). J. Agric. Sci. Mansoura Univ., 26 (3): 1873-1882.

El-Fayoumy, M.E. and H.M. Ramadan (2002). Effect of bio-organic manures on sandy soils amelioration and peanut productivity under sprinkler irrigation system. Egypt. J. Soil Sci., 42 (3): 383.

El-Mancy, M.H.A.; E.M. Selim and N.A. Atia (2008). Combined effect of organic and mineral fertilizers on yield of potato grown under coarse-textured soil conditions. Egypt. J. Soil Sci., 48 (1): 31-43.

El-Shazly, M.M. (2008). Potassic, organic and bio-fertilization of potatoes under alluvial soil conditions. Ph. D. Thesis, Fac. of Agric., Mansoura, Univ., Egypt.

Fayoum J. Agric. Res. \& Dev., Vol.25, No.1, January, 2011 
Ghorbani, R.; A. Koocheki; M. Jahan and G.A. Asadi (2008). Impact of organic amendments and compost extracts on tomato production and storability in agroecological system. Agro. J., 28: 307-311.

Ghosh, D.S. and M. Mohiuddin, (2000). Response of summer sesame (Sesamum indicum) to biofertilizer and growth regulator. Agric. Sci., Digest., 20: 90-92.

Havlin, J.L.; J.D. Beaton; S.L. Tisdale and W. L. Nelson (2005). Soil Fertility and Fertilizer. Upper Saddle River: Pearson Prentice Hall.

Hewedy, A.M. (2000). Effect of methods and sources of potassium application on the productivity and fruit quality of some new tomato hybrids. Egypt. J. of Agric. Res., 78 (1): 227-244.

Jackson, M.L. (1973). Soil Chemical Analysis. Prentice-Hall of India Private Limited, New Delhi. India.

Khan, N.A.; M. Mobin and Saiullah (2005). The influence of gibberellic acid and sulphur fertilization rate on growth. Plant and Soil, 270 (1): 269-274.

Kloepper, J.W. (2003). A review of mechanisms for plant growth promotion by PGPR. 6th international PGPR workshop. 65-10 October 2003, Calcutta, India.

Lifshutz, R.; J.W. Kloepper and M. Kozolowski (1987). Growth promotion of canola (rapeseed) seedlings by a strain of Pseudomonas putida under genobiotics conditions. Can. J. Microbial., 33:390-395.

Lindsay, W.L. and W.A. Norvell (1978). Development of DTPA soil test for Zn, Fe, $\mathrm{Mn}$ and Cu. Soil Sci. Soc. Am. J., 42: 421.

Lugtenberg, B.; T. Chin-A-Woeng and G. Bloemberg (2002). Microbe-plant interaction: Principles and Mechanisms. Antonie Van Leeuwenhoek, 81: 373-383.

Makaraviciute, A. (2003). Effect of organic and mineral fertilizers on the yield and quality of different potato varieties. Agro. Res., 1 (2): 197-209.

Markus, D.K.; J.P. Mckinnon and A.F. Buccafuri (1982). Automated analysis of nitrate and ammonium nitrogen in soils. New Jersey Agric. EXP Sta. Publication No. D.15117-84, Supported by State Funds Presented Impart before Div. 5-4, Soil Soc. of Am. Anaheim, CA.

Massoud, A.M.; H.M. Salem; I.M. Farid and M.A. Nasef (2004). Response of pea plants grown on a clay soil to Rhizobium Inoculation combined with Mo and $\mathrm{Zn}$ as foliar application. Annals of Agric. Sci., Moshtohor, 42 (3): 1431-1440.

Massoud, A.M.; M.Y. Abou-Zeid El-Sayeda; A. Hassan and S.F. El-Fiki (2008). Influence of phosphate dissolving and nitrogen fixing bacteria on faba bean under different levels of phosphorus fertilization. J. Agric. Sci. Mansoura Univ., 33 (11): 7991-8007.

Mezuan, I.; P. Handayani and E. Inoriah (2004). Application biofertilizer formulation for plant cultivation rice. J. Sci. Agric. Indian., 4 (1): 27-34.

Mikitizal, L.J. (2004). Gibberellic acid effects on potato yield and morphology. Potato Assoc. of Amer. (PAA) 88 ${ }^{\text {th }}$ Annual Meeting, Aug. 8-12.

Mohammed, S.S. (2004). Assessment of the relative effectiveness for some organic materials conjucted with mineral nitrogen on soil fertility status, yield and quality of wheat grown on a newly cultivated soil. Egypt. J. Appl. Sci., 19 (3): 298-310.

Mohanty, B.K. and J.N. Das (2002). Response of rabbi onion cv. Nasik Red to nitrogen and potassium in fertilization. Vegetable Sci., 28 (1): 40-42.

Fayoum J. Agric. Res. \& Dev., Vol.25, No.1, January, 2011 
Nassar, K.E. (1997). Some factors affecting the absorbtion of micronutrients by plants. Ph. D. Thesis, Fac. of Agric., Menofiya Univ., Egypt.

Rupert, L.H.; N. Breward; S.C. Young; N.M.J. Crout; A.M. Tye; A.M. Moir and I. Thornton (2004). Assessing potential risk of heavy metal exposure from consumption of home-produced vegetables by urban population. Environ. H. Pres., $112(2)$.

Santosh-Sahay and B.P. Singh (2004). Effect of cropping and nutrient use on yield and protein of wheat. J. of Res., Birsa-Agric. Niv., 16 (2): 197-201.

Sarhan, S.H.; H.K. Zaki and E.N. El-Banna (2004). Impact of organic and inorganic fertilization on yield, tuber contents and some heavy metals concentration in potato tubers. J. Agric. Sci. Mansoura Univ., 29 (5): 2753-2760.

Selim, E.M. and M.H.A. El-Mancy (2007). Productivity of tomato plants treated with some biological, organic and inorganic fertilizers. Egypt, J. Appl. Sci., (In Press).

Sharma, A.R. and B.N. Mittra (1991). Effect of different rates of application of organic and nitrogen fertilizers in a rice based cropping system. J. Agric. Sci. Cambridge, 117: 313-318.

Shehata, M.M. and S.A. El-Khawas (2003). Effect of two biofertilizers on growth parameters, yield characters, nitrogenous components, nucleic acids content, minerals, oil content, protein profiles and DNA, banding pattern of sunflower (Helianthus annuus, L. cv. Vedock) yield. Pakistan J. of Bio. Sci., 6 (14): 12571268.

Simmanungkalit, R. (2001). Application biofertilizer and chemical fertilizer. Bull. Agro. Bio., 42: 56-61.

Snedecor, G.W. and W.G. Cochran (1980). Statically Methods. 7th Ed., State Univ., Press, Amer. 9, Iowa, USA.

Spooner, D.M. and J.B. Bamberg (1994). Potato genetic resources: Sources of resistance and systematic. Am. Potato J., 71: 325-338.

Soltanpour, P.N. and A.B. Schwab (1977). A new soil test for simultaneous extraction of macronutrients in alkaline soils. Comm. Soil Sci. and Plant Annals, 8: 195.

Straaten, P.V. (2002). Rocks for Crops. ICRAF, Nairobi, Kenya, 38 pp.

Srikumar, T.s. and P.A. Ockerman (1990). The effect of fertilization and manuring on the content of some nutrients in potato (var. pivoita). Food Chem., 37: 47-60.

Sys, C. and W. Verheye (1978). An attempt to the evaluation of physical land characteristics for irrigation to the FAO framework for land evaluation. Int. 1, Trai. Cent. Post Grad. Soil Sci., Ghent, Belgium.

Sys, C.; E. Van Ranst; J. Debaveye and F. Beernaert (1993). Land evaluation. Part III, Crop Requirements Agricultural Publication No.7, General

Szajdak, L.; L. Zyczynska-Baloniak; T. Meysner and A. Blecharezyk. (2004). Bound amino acids in humic acids from arable cropping systems. J. of Plant Nutrition and Soil Sci., 5 (167): 562.

Talley, E.A. (1983). Protein nutritive value of potatoes is improved by fertilization with nitrogen. Amer. Potato J., 60: 35-40.

USDA (2010). Key to Soil Taxonomy. $11^{\text {th }}$ Ed., United States Department of Agriculture, USA.

Fayoum J. Agric. Res. \& Dev., Vol.25, No.1, January, 2011 


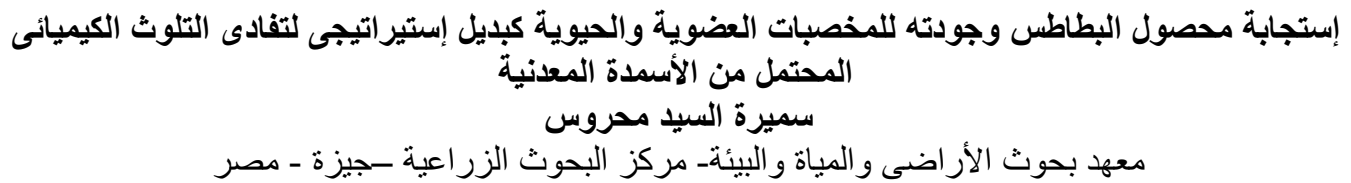

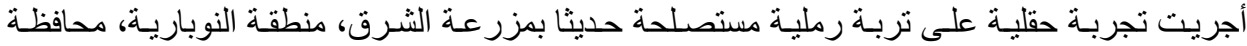

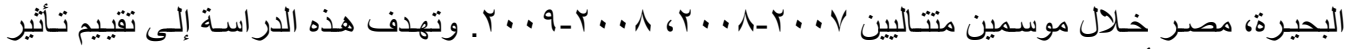

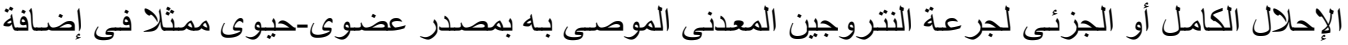
(N مكور عضوى مع التلقيح الحيوى لتقاوى البطاطس بيكتيريا مثبتـة حيويـا للنتروجين P-dissolving bacteria of Bacillus Cyanobacteria) (megatherium var. phosphaticum)

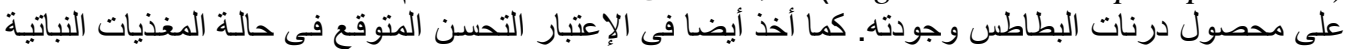

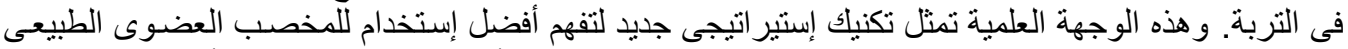

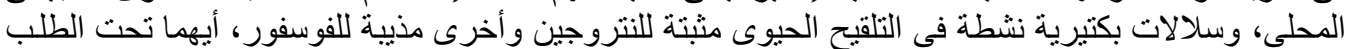

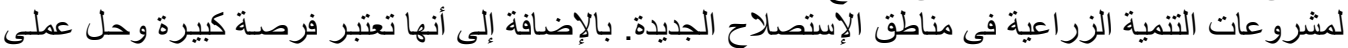

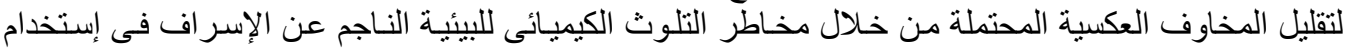

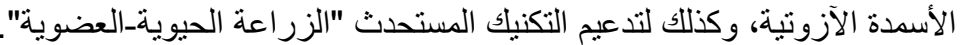
ولتحقيق الهدف من هذه الدر اسة، تم زر اعة تقاوى من قطع درنات البطاطس الملقحة حيويا Solanum tuberosum, L. Lady balfour cv.)

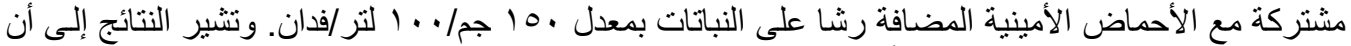

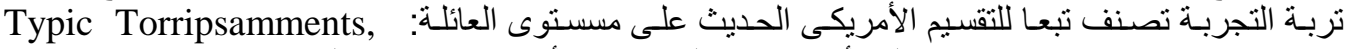

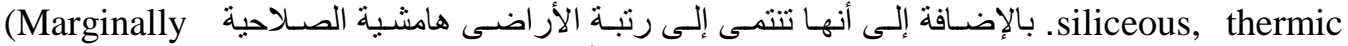

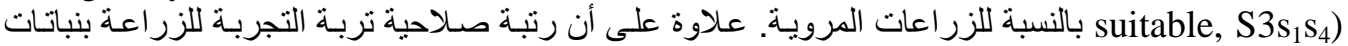

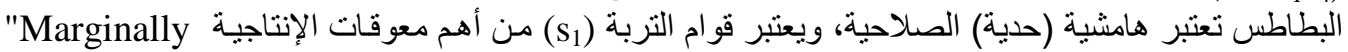
suitable $\left(\mathrm{S} 3 \mathrm{~s}_{1}\right)$ adaptation"

وتشير النتائج إلى أن إضـافة المكمور العضوى إلى التربـة يزيد محتو اهـا من المغذيـات النباتيـة الميسرة

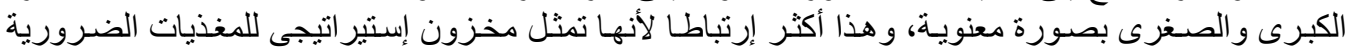

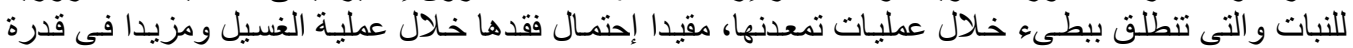

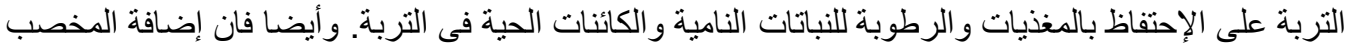

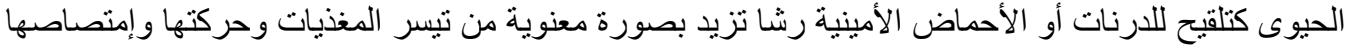

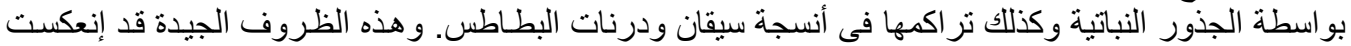

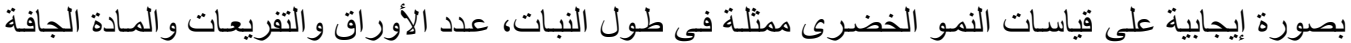

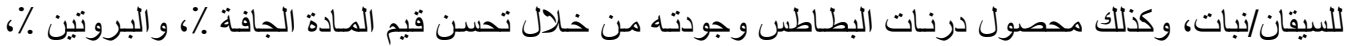

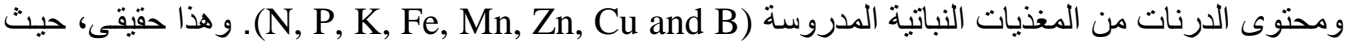

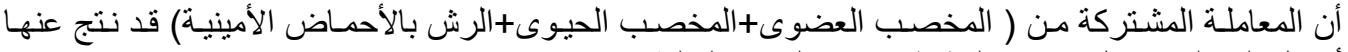

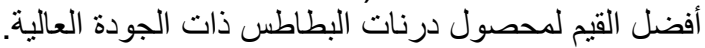

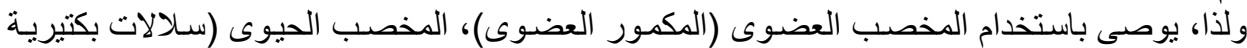

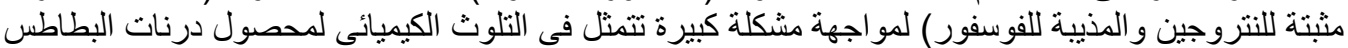

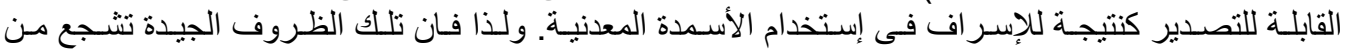

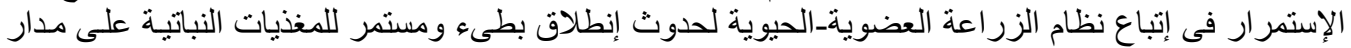

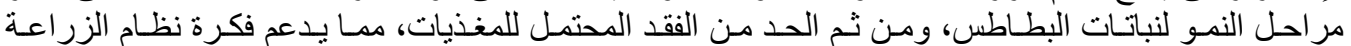

